\title{
An it multinational company innovating in the latin america region based on external signals An exploratory case study of how a global t-KIBS company innovates acquiring external signals and converting them into innovation
}

\author{
Celso dos Santos Malachias Doutor em Administração de Empresas. Fundação Getúlio Vargas (FGV) - Brasil. celso.malachias@gmail.com \\ Luiz Carlos Di Serio Doutor em Engenharia Mecânica. Fundação Getúlio Vargas (FGV) - Brasil. luiz.diserio@fgv.br
}

\begin{abstract}
The main objective of this exploratory qualitative case study research is to study the external knowledge acquisition and opportunities translation into innovations. In order to reach this goal it is proposed to use the Peripheral Vision and Absorptive Capacity constructs as lens to study the phenomenon. These two elements composed and combined form a four-phases framework - source, monitoring, interpretation and conversion, which was applied in a Latin America subsidiary of a large Multinational Information Technology Services company. The innovation outcomes were explored as performance evidences of the framework as an innovation process mechanism. As findings we could realise evidences the company seeks and generates innovation mainly using their clients as source, having as outcome, process innovations, with incremental impact. Also we saw the different leadership perspectives about the importance of innovation phases in the framework.
\end{abstract}

Keywords: Innovation. Peripheral Vision. Absorptive Capacity.

\section{Uma multinacional de Tl inovando na região da américa latina baseado em sinais externos Um estudo de caso exploratório de como uma empresa global de t-KIBS inova adquirindo sinais externos e convertendo-os em inovação}

\begin{abstract}
RESUMO
O principal objetivo deste estudo exploratório, pesquisa qualitativa estudo de caso é estudar a aquisição do conhecimento externo e tradução de oportunidades em inovações. Com o objetivo de atingir esta meta é proposto o uso dos construtos Visão Periférica e Capacidade Absortiva como lentes para estudar o fenômeno. Estes dois elementos compostos e combinados definem um framework de quatro fases - fonte, monitoramento, interpretação e conversão, e foi aplicado em uma subsidiaria da América Latina de uma grande multinacional de serviços de tecnologia da informação. Os resultados da inovação foram explorados como evidências de desempenho do framework como um mecanismo do processo de inovação. Como resultados pudemos ver evidências que a empresa busca e gera inovação principalmente usando seus clientes como fontes de busca, tendo como resultado, principalmente, inovações em processo, com impacto incremental. Também vimos as diferentes perspectivas da liderança sobre a importância das fases da inovação do framework.
\end{abstract}

Palavras-chave: Inovação. Visão Periférica. Capacidade Absortiva. 


\section{INTRODUCTION}

Currently the companies are facing high competition in their business environment. Huge volumes of data are emerging every day. Many signals appear in their market. In such context, how can the company acquire and translate some of these signals into innovation? In order to answer that question, this research studies the knowledge acquisition, based on a proposed framework composed by two main elements, the peripheral vision and the absorptive capacity. Considering the specific characteristics of services sector, this exploratory study has as main research objective to analyse the acquisition and interpretation processes from the external environment, through the constructs, Absorptive Capacity (COHEN; LEVINTHAL, 1990; ZAHRA; GEORGE, 2002) and Peripheral Vision (DAY; SCHOEMAKER, 2005), to the generation of ideas and innovations. As a secondary objective, evidences have been explored for each one of the phases, as driver elements for innovation (CROSSAN; APAYDIN, 2010). As evidence to confirm both constructs can foster innovation we sought for innovation as outcome (TIDD; BESSANT; PAVITT, 2005).

\section{LITERATURE REVIEW}

In this section the main theoretical concepts and constructs used in this research are discussed. The main constructs are Peripheral Vision (PV) (DAY; SCHOEMAKER, 2005; SCHOEMAKER; DAY, 2009) and Absorptive Capacity (AC) (COHEN; LEVINTHAL, 1990; ZAHRA; GEORGE, 2002). The main topics in the literature review are presented in the Figure 1.

Figure 1 - The main theoretical concepts discussed in this paper

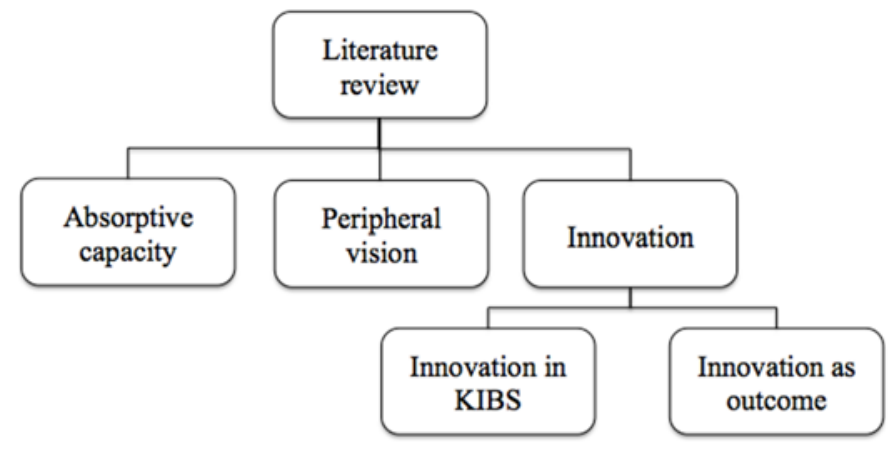

Source: Authors (2017).

\subsection{Peripheral Vision}

Peripheral vision concept comes from medicine (RAPPAPORT, 2014), and was brought from medicine into business administration by the researchers (DAY; SCHOEMAKER, 2005). The main idea of this construct in administration is the company possibility to have a broader vision, or to look in their periphery, not just in their current focal vision. The focal vision is typically the day by day operation scope, in their current economic sector, solving and attending client's problems and selling products to their clients. According to the authors (SCHOEMAKER; DAY, 2009) the Peripheral Vision construct is composed by some phases and correspondent activities, briefly described here as:

- Scope (or here also called Source): it is to where the company focus their vision, where the company can collect signals of opportunities or threats,

- Monitoring: it refers to how the companies look outside their boundaries, whether, proactively or reactively, close or far to their current knowledge,

- Interpretation: it's related to giving meaning to the signals, to evaluate the external signals (or also called here events) in relation to previous patterns, also called sensemaking (WEICK, 1984),

- Action and screening: after interpreting the data, converting them into information, what the company should do, what action should be taken? ,

- Feedback and adjusts: after completing the previous steps and corresponding activities, the company should evaluate how that action was received or incorporated in their process or products. This phase also could be called as a learning process (SENGE, 1990).

In this research we will apply the four firsts phases, from scope, until action. 


\subsection{Absorptive Capacity}

Absorptive Capacity, according to Cohen and Levinthal (1990) refers to the company's capability to see value in an external knowledge, capture and transform it in something new and valuable. In order to execute these previous processes the company should use their resource and development (R\&D) competence. Zahra and George (2002) study the same phenomenon of acquiring an external signal, in a different way. These authors split the Absorptive Capacity in two main blocks, the potential capacity and the realized capacity. The potential capacity is composed of two smaller activities, such as, acquisition and absorption. The second part, realized capacity, it is composed by knowledge transformation and exploitation, creating in this way, new products and new revenues. Under these authors' perspective it is possible to evaluate how much is available to extract value of the external knowledge, and how much, effectively, the company extracted.

This study could be related to the Regnér's (2003) article where the author discusses two different strategy creation according to company perspective, either in a more central view, or in a more peripheral vision, executing activities and developing strategies more deductive or inductive, respectively. In this comparison the current study related the studied phenomenon to more exploratory initiatives (inductive) rather than exploitive (deductive) ones as March (1991) exposed.

The main objective in this research is to study how the company acquires an external signal. As secondary objectives this study aims to analyse where the company looks for acquire an external signal, how much of these signals are converted into innovation, what kind of innovation are generated,the outcomes and impacts.

With the two constructs, individually, we could seek to analyse the mentioned study objectives. The idea of to use both constructs, peripheral vision and absorptive capacity, is to study more details about the phenomenon, of acquiring an external signal, absorbing and converting it into innovation.

\subsection{Knowledge database}

As we will see in the item innovation in services, research and development (R\&D) formal function for product development is very important in product manufacturing industries, but not so much important in services sector. Absorptive Capacity uses the R\&D formal function as the seminal authors propose the construct studying manufacturing industries. In our study we are giving emphasis to the company knowledge database, once the diversity of knowledge is driver element to generate more meaning (WEICK, 1984) and more innovations (COHEN; LEVINTHAL, 1990; UTTERBACK, 1971).

\subsection{Innovation}

The innovation focus used here is innovation as outcome, rather than, study of the internal process of innovation, or innovation as a process. The main authors used to conceptualize innovation are Crossan and Apaydin (2010). According to these authors innovation is related to acquisition, assimilation and exploration of value-added novelty in economic and social aspects. It can be both, process and outcome (CROSSAN; APAYDIN, 2010). Adding the OECD Oslo Manual (OECD, 2005), Armbruster et al. (2008) and Crossan and Apaydin (2010), we have the following types of innovations, as outcome:

- Product Innovation: refers to improvement or new products or services,

- Process Innovation: refers to new information of material flow inside or across the business units, and new work principles, method, papers or tools utilized in business process,

- Marketing Innovation: refers to a new marketing method, involving significant changes in product design or packaging, product placement, or price,

- Organization Innovation: it is divided in two types, structural innovation and procedural innovation. The structural innovation refers to creation or elimination of hierarchical levels, specialized teams, layout, and new industry vertical focus, among some examples. The procedural innovation, less tangible, refers to procedures, practices, new management way, quality programs, or idea suggestions,

- Business Model Innovation: refers to strategic choices to create and capture value over the business chain, connecting providers, clients and complementary assets. 
With these main theoretical elements this research worked in the fieldwork to find evidences that the Peripheral Vision and Absorptive Capacity can work as drivers to innovation based on external signals. The next sections, methodology and findings will discuss the method to acquire information from the interviewees about how they deal with those constructs, in a practical way, and what was found.

\subsection{Innovation in Services}

The traditional service sector, known typically as non-innovative (KON, 2004), has some specific segments which have high innovation rates as mentioned in Howells (2000), such as the t-KIBS (technological Knowledge Intensive Based Sector) (MILES, 1995). Specifically in t-KIBS there are some differences in the innovation process. Beyond the R\&D, other factors appear as relevant in services innovation, such as, client and providers relationship, as mentioned by Howells et al. (2004).

Therefore, under the context presented in the literature review the idea is to evaluate the influence of some key factors mentioned in this theoretical section, aiming to explore and study a t-KIBS company acquiring an external signal to innovate. We will use the here called composed peripheral vision framework. In the methodology there will be details about the relevant aspects questioned to the interviewees.

The main concepts, authors and papers are shown in the Table 1.

Table 1 - Main concepts, authors and papers (or books)

\begin{tabular}{ll}
\hline Concepts & Authors and papers (books) \\
\hline Peripheral Vision & Day and Schoemaker (2005), Schoemaker and Day (2009). \\
Absorptive Capacity & Cohen and Levinthal (1990), George and Zahra (2002) \\
Interpretation & Weick (1984) \\
Innovation & Crossan and Apaydin (2010), OECD (2005), Ambruster et al. (2008) \\
Innovation in Services & Howell et al. (2004) \\
t-KIBS & Miles et al. (1995), Howell (2000) \\
Methodology & Eisenhardt (1989), Lewis (1998), Yin (2010), Bekhet (2011) \\
\hline
\end{tabular}

\section{METHODOLOGY}

This section describes some methodology research aspects such as, the research approach, research technique, industry segment company based, the company used as case study, the interviewees profile, among others research technical aspects.

\subsection{Research approach}

The fieldwork research method applied was qualitative, through a case study. According to Yin (2010, p. 39) this methodology is "an empirical inquiry that investigates a contemporary phenomenon in depth and in its real life context, especially when the boundaries between phenomenon and context are not clearly evident". One's Eisenhardt's (1989, p. 548-549) conclusion in her study about "building theory from case studies" is that this process of theory building "is particularly well-suitable to new research areas or research areas for which existing theory seems inadequate". Through semi-structured detailed interviews, a Multinational Information Technology (IT) company (also known as t-KIBS, which stands for, Technological Knowledge Intensive Services), according to Miles et al. (1995) was used in this research. The unit studied was a Latin America regional subsidiary with more than 4,000 employees in all region. In order to improve the data rigor,a triangulation strategy (LEWIS, 1998; BEKHET; ZAUSZNIEWSKI, 2011) was used, adding the observation method, and access to secondary public data in company websites. The executives interviewed in this research are positioned in a high hierarchic level of Latin America region organization, and therefore, have a strategic view of the 
corporate practices, and strategic view, and theoretically, therefore, they are able to provide answers on behalf of the company about the scope involved in this study. More information about the executives interviewed is provided in the item The Interviewees.

\subsection{The Industry Segment}

The Information Technology (IT) industry segment, also known as t-KIBS (stands for technological knowledge intensive services) as in Miles et al. (1995) has high relevance in terms of revenue. According to Gartner (2016) the global IT market size is about US\$ 4 trillion as seen in the Figure 2.

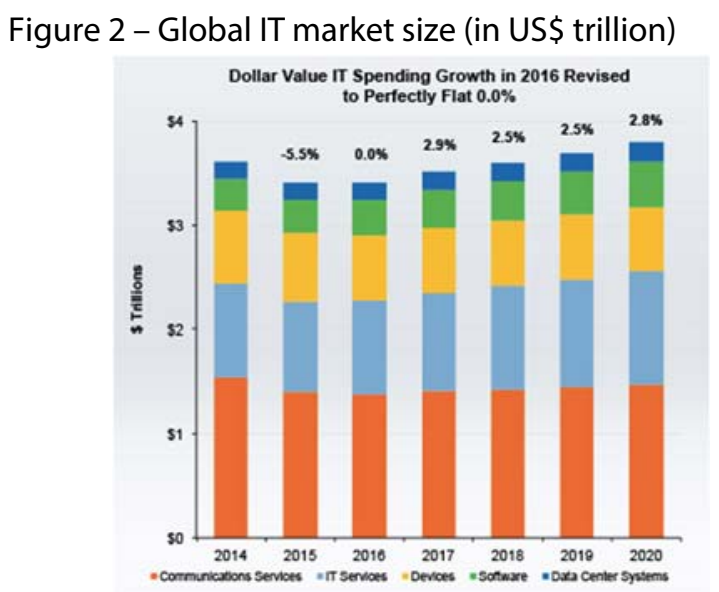

Source: Gartner (2016).

\subsection{The company}

The company is a Public Information Technology American Multinational with stocks at NASDAQ Stock Market. Their Global revenue is about US\$ 3 billion (2015). The company has about 4,000 employees in Latin America, but it is a closed company and it doesn't disclose numbers about revenue or other financial data, considered sensitive and confidential information. In this research we will call it as The Company.

\subsection{The interviewees}

The interviewees are three top executives in the Latin America (LATAM) and Brazil hierarchy. Their roles are: LATAM CEO, LATAM Operations VP and Brazil Sales VP. They were chosen because, as they are in a high hierarchic level, they have knowledge and power to answer on behalf of the company. They also have access to strategic information as those demanded in this research, once the desirable data for this study implies in having a global and strategic company view. In the Table 2 it is possible to see some descriptive data about the three interviewees.

Table 2 - Descriptive data about the company leaderships interviewed

\begin{tabular}{|c|c|c|c|c|c|}
\hline Role & $\begin{array}{l}\text { Academic } \\
\text { Graduation }\end{array}$ & $\begin{array}{r}\text { Experience } \\
\text { (Years) }\end{array}$ & $\begin{array}{l}\text { Function } \\
\text { (years) }^{1}\end{array}$ & Responsibility & Observations \\
\hline LATAM CEO & $\begin{array}{l}\text { Computer } \\
\text { Science }\end{array}$ & 30 years & 3.5 years & $\begin{array}{l}\text { Full P\&L (Profit \& Loss), } \\
\text { about 4k employees }\end{array}$ & $\begin{array}{l}\text { He supports and stimulates } \\
\text { the changes. }\end{array}$ \\
\hline $\begin{array}{l}\text { LATAM } \\
\text { Operations } \\
\text { VP }\end{array}$ & $\begin{array}{l}\text { Computer } \\
\text { Science }\end{array}$ & 38 years & 03 years & $\begin{array}{l}\text { Services: Solution design, } \\
\text { Pre-Sales, Delivery and } \\
\text { Operation }\end{array}$ & $\begin{array}{l}\text { He has lived in } 3 \text { countries } \\
\text { outside Brazil: Portugal, } \\
\text { USA and Finland. He lives } \\
\text { the ambidexterity } \\
\text { challenge. }\end{array}$ \\
\hline
\end{tabular}




\begin{tabular}{|c|c|c|c|c|c|c|c|}
\hline $\begin{array}{l}\text { Brazil } \\
\text { VP }\end{array}$ & Sales & $\begin{array}{l}\text { Computer } \\
\text { Science }\end{array}$ & 30 years & $\begin{array}{l}03 \quad y \\
\text { and } \\
\text { months }\end{array}$ & $\begin{array}{r}\text { years } \\
04 \\
5\end{array}$ & $\begin{array}{l}\text { Brazil Sales, which } \\
\text { represents about } 50 \% \text { of } \\
\text { the total LATAM revenue } \\
\text { and businesses. }\end{array}$ & $\begin{array}{l}\text { He has the initiative to } \\
\text { change the sales process } \\
\text { and mainly the mental } \\
\text { model of his team to } \\
\text { expand their view in } \\
\text { opportunities analysis. }\end{array}$ \\
\hline
\end{tabular}

Source: Authors (2017).

Note 1: Time of respondent in the function, measured in years.

\subsection{Research Methodology}

In this case study, interviews with open-ended questions and the critical incident technique were used (GREMLER, 2004). This technique aims to get evidences of conversion from signals in the market into innovations, as a way to exemplify potential support of the main constructs as drivers to innovations acquired externally. The primary data acquired through the interviews was added and compared with the second data obtained through public data such as the company website, in a methodological triangulation, as a way to increase the validity of data and improve the interpretation and possibly suggest theories (BEKHET; ZAUSZNIEWSKI, 2011, p. 40), or in their words "It has been found to be beneficial in providing confirmation of findings, more comprehensive data, increased validity and enhanced understanding of studied phenomena".

\subsection{Research Protocol}

In the beginning of the interviews, the interviewers read some topics about research confidentiality, or nondisclosure agreement, about our understanding of innovation, among other specific points. The aim of these statements was to standardize the concepts and have a common scale and have the interviewees comfortable with the anonymity and data confidentiality. As our innovation understanding we use the concept of Crossan and Apaydin (2010, p. 1155) which says:

Innovation is: production or adoption, assimilation, and exploitation of a value-added novelty in economic and social spheres; renewal and enlargement of products, services, and markets; development of new methods of production; and establishment of new management systems. It is both a process and an outcome.

\subsection{Topic Outline}

In order to obtain evidences of the propositions here discussed that the Peripheral Vision and Absorptive Capacity are drivers to innovation based on signals acquired externally, we created the following topic outlines aiming to address the main concepts involved in the theory. This outline served as a guideline to generate the open-ended questions in the interviews. The Table 3 shows the main topics.

Table 3 - Main theoretical elements and their meaning and/or aim

\begin{tabular}{ll}
\hline Main elements & Meaning (get evidences of) \\
\hline Sources & Identify at where they are looking outside \\
\hline Interpretation & Knowledge database diversity \\
Monitoring & Frequency, way (reactive or proactive) \\
Type of innovation & Product, process, structural, business model \\
Innovation as outcome & Example of innovations produced \\
Innovation impact & Incremental or disruptive \\
Composed framework & The most important framework phase(s) \\
\hline & Source: Authors (2017).
\end{tabular}




\section{FINDINGS AND DISCUSSIONS}

In this section the main findings collected in the fieldwork are discussed, and, as well, the analysis about it. They are split in main topics of findings and named by a summary.

\subsection{General findings and analysis}

The interviewed executives have in common a client centric view; they are oriented to client experience and satisfaction. Most innovations found were incremental, as innovations involving clients typically result in incremental innovations (MILES et al., 1995). In terms of the relevance of framework phases for innovation generation, based on market signals, the three main functions, General Management, Operations and Sales, have slightly different visions. The CEO and Sales VP see source, monitoring and interpreting phases as the most important to generate innovation. The Operations VP considers the conversion phase as the key contributor to the innovation process. Therefore, the framework was confirmed as a mechanism to drive innovation. Another finding was the ambidexterity (O'REILLY; TUSHMAN, 2008) behaviour in the Operations area, since it has to deliver the services accordingly with contract Service Level Agreements (SLAs), and at the same time the area needs to implement many innovations, dealing with new technologies, new technologies even for the global corporation.

\subsection{Primary data}

The Table 4 reflects some of the primary data found in the interviews.

Table 4 - Summary with leadership's answers about key concepts

\begin{tabular}{|c|c|c|c|}
\hline Objectives & CEO & Operations VP & Sales VP \\
\hline $\begin{array}{l}\text { Innovation Search } \\
\text { Sources }\end{array}$ & $\begin{array}{l}\text { Clients, competitors, new } \\
\text { employeer hiring } \\
\text { (competitors knowledge) }\end{array}$ & $\begin{array}{l}\text { Clients, new employee hiring } \\
\text { (competitors knowledge), } \\
\text { partners }\end{array}$ & $\begin{array}{l}\text { Clients, business environment } \\
\text { (political and economics), } \\
\text { tendencies, market analysts, } \\
\text { other geographies (USA and } \\
\text { Europa) }\end{array}$ \\
\hline $\begin{array}{l}\text { What is most dynamic } \\
\text { and complex to } \\
\text { monitor? }\end{array}$ & 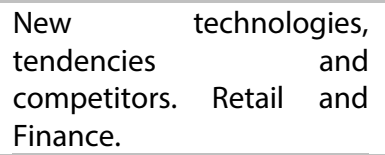 & $\begin{array}{l}\text { New technologies, tendencies } \\
\text { and competitors. }\end{array}$ & $\begin{array}{l}\text { Clients, regulatory, tendencies. } \\
\text { Currently perceives company } \\
\text { search for Knowledge further } \\
\text { than current one. }\end{array}$ \\
\hline Interpretation & $\begin{array}{l}\text { Think Tank meeting; low } \\
\text { diversity in the team deal } \\
\text { with market }\end{array}$ & $\begin{array}{l}\text { Global system review based on } \\
\text { rich written narratives in } \\
\text { Microsoft Word (not in } \\
\text { Microsoft Power Point) }\end{array}$ & $\begin{array}{l}\text { Two meetings: one of sales with } \\
\text { an extended team and } \\
\text { diversified, and one about } \\
\text { strategic themes (beyond sales } \\
\text { team) }\end{array}$ \\
\hline $\begin{array}{l}\text { Innovation outcome } \\
\text { examples }\end{array}$ & $\begin{array}{l}\text { Organisational structure } \\
\text { more horizontal, building } \\
\text { change, spontaneous } \\
\text { media, zero cost in client } \\
\text { events (business partners } \\
\text { support). }\end{array}$ & $\begin{array}{l}\text { Help Desk process, new CRM } \\
\text { software, WhatsApp support in } \\
\text { corporate solutions, global } \\
\text { review meeting using rich } \\
\text { narrative trough Microsoft } \\
\text { Word. }\end{array}$ & $\begin{array}{l}\text { Differentiated deal pre } \\
\text { qualification process, in an } \\
\text { extended and diversified } \\
\text { meeting; industry } \\
\text { segmentation; relationship } \\
\text { events. }\end{array}$ \\
\hline $\begin{array}{l}\text { Innovation impact } \\
\text { (by products } \\
\text { launched in the latest } \\
\text { three years) }\end{array}$ & $\begin{array}{l}\text { Profit Margin increase of } \\
3 \% \text { to } 4 \% \text { year over year. }\end{array}$ & $\begin{array}{l}\text { Cost reduction, productivity } \\
\text { increase, more offering variety, } \\
\text { more customized solutions. }\end{array}$ & $\begin{array}{l}\text { Revenue increase of } 5 \% \text { yearly; } \\
\text { sales cycle reduction (due to } \\
\text { better qualification); cost } \\
\text { reduction in current offering } \\
\text { (due to datacentre sales to a } 3^{\text {rd }} \\
\text { party business partner). }\end{array}$ \\
\hline $\begin{array}{l}\text { Most frequent } \\
\text { innovation type. }\end{array}$ & $\begin{array}{l}\text { Process, organisational } \\
\text { (structure). }\end{array}$ & $\begin{array}{l}\text { Process, } \\
\text { (procedural), } \\
\text { (services). }\end{array}$ & Process. \\
\hline $\begin{array}{l}\text { What is the most } \\
\text { important phase in } \\
\text { the framework? }\end{array}$ & $\begin{array}{l}\text { Identification where to look } \\
\text { for (sources) and } \\
\text { interpretation. }\end{array}$ & $\begin{array}{l}\text { From idea to innovation } \\
\text { conversion. }\end{array}$ & $\begin{array}{l}\text { Identification (sources), } \\
\text { monitoring and interpretation. }\end{array}$ \\
\hline
\end{tabular}

Source: Authors (2017). 


\subsection{Secondary data}

From the company's website it was learned they have a Global Innovation Policy (GIP) as one of their strategic actions. Their other strategic actions are: Strategic Business Planning, Service Excellence, and Governance). Their GIP fosters client proximity initiatives and a Client Experience Maturity Level. Thus, we realized that the innovation policy or innovation orientation drive and support to all actions in client's direction. It is aligned with the feedback and perceptions in the leadership's statement.

\subsection{General considerations}

In this topic the main results and an analysis of these results are discussed.. The results and their possible meaning are split in subject topics, for a clearer understanding of each matter.

\subsection{Contingency context}

Crisis affects the macro economic environment in the Latin America region, mainly Brazil. Many changes are perceived in the information technology industry and also in the company globally, where the global CEO has changed in 2014.

\subsection{Client focus}

The common ground among the three leaders is the client focus. Clients are the main reason for changes and the internal changes, in process or products, occur always using the client as justification. The perception of the three executives interviewed is that the company, in their opinion, is very traditional due to more than hundred years of existence, and also because of the company's global and consolidated process which is difficult to change. Despite that, the company gives some space to implementation of changes, or customization of global practices for the Latin America region, but always using the client perspective or client justification to install new processes, new organization structures, new products or proceed a product customization.

The executives attitudes about innovation and orientation to their employees are aligned and supported by the Global Innovation Policy (GIP), as mentioned earlier, which means they have a total focus in clients.

\subsection{Innovation impact}

As seen previously, clients are the company's main focus. In the principal actions done in the company, clients are the reason, and innovation is a consequence; considering client is inside the depth search strategy, possibly more incremental innovation would result as an outcome, as seen in Laursen and Salter (2006).

\subsection{The Innovator's Dilemma}

On the one hand the company sees the need to preserve the current solution offerings and process, but on the other hand, there is the need to approach new demands and new processes internally, in the company, as well as externally, in relation to their clients and prospects.

The Innovator's dilemma stated in the Christensen's book (1997) is present in the company, once their clients and prospects are demanding for software and IT solution as a service or in the cloud. Currently, most of their revenue come from the software and solutions sales ("on premises"). The Information Technology industry segment is changing to cloud solutions, where the client pays by service usage, in a monthly rental disbursement. Therefore, the company's challenge is to keep the revenue and shareholders happy, once with the new business model (cloud), the revenue comes diluted in long-range contracts while in the previous model, the client used to pay huge amount of money in shorter 
term. And more, in the previous business model, clients used to buy the asset, the solution. Currently it's a rental or leasing model, where clients don't need to acquire the asset, just use it, when they want.

\subsection{Ambidexterity}

The operation area (services delivery) lives the ambidexterity challenge, it means, it has to deliver the agreed contracts, reach or surpass the SLAs forecasted in the contracts, and at the same time, innovate systematically, aiming to reduce costs and increase productivity, as expected in their goals. In this they can increase the profit margin in the operation area. They innovate more in process rather than other innovation types. Innovate in both ways, reactive and proactive. Reactive when the clients ask for changes,

\subsection{Process and product innovation}

The company innovates in both, products and process. But most of the innovations are in process, in structure, organizational and in procedures.

\subsection{Proactive or reactive way}

The company innovates in both ways, reactive and proactive. Reactive when the client asks for changes, for instance, in a solution offering customization. Proactive when the company anticipates some client changes, for instance, when the Operations Delivery VP is notified that its client's president has been replaced for a new one. The VP, perceiving some cost reductions action done by the client's new CEO in their company, studies the current contract and decides proactively propose a cost reduction in the contract before the formal expiration of the contract term in one year ahead.

Another example of proactive innovations occurs when the company appears spontaneously, and freely, in the media channels, such as online, press, etc. The leadership initiative to meet or have lunch with journalists, to talk about the company's news, shows a fruitful strategy to generate procedure innovation, and possibly more clients and prospects.

\subsection{Innovation stimulated by the leadership}

Manly the CEO stimulates the changes, with his behaviour and attitudes, to implement organizational innovations, such as structural, procedures and also in process. He is the main support and stimuli to changes and supports the leaderships, who directly report to him.

\subsection{Contingency innovation}

Some innovations are contingent on external environment conditions such as, in Brazil, due to the economic crisis, they negotiated their new Brazilian office rental contract in a lower budget than the previous contract and also received from the building owner a US\$ 500k budget to buy new furniture. In addition, another example of contingency innovation, again due to low economic business environment context, is that they replaced long-term and expensive employees with new and less expensive employees.

\subsection{Innovation generated by a differentiated perspective}

The sales head innovates in process and in a proactive and differentiated way, as for example, in the "qualification" sales phase, where he inserted new analysis element, as what he calls client industry segment "dynamic". He calls dynamic the industry trends, technological changes, and regulatory impact, political or economic. In this way, he and his team are able to choose clients (!) and reduce the prequalification sales cycle in about $40 \%$. Therefore, instead of, for instance, close a deal in six months, they can close the same deal, in about 4 months. In terms of outcome, this is a process innovation with important impact. 


\subsection{Different functions, different perspectives}

According to the composed framework used in this research the executives were asked their perception about what phase(s) was (were) the most important to generate innovation based on external signals. The leadership vision about the important phases in the composed peripheral vision framework was as shown in the Figure 3.

Figure 3 - Composed Peripheral Vision Framework

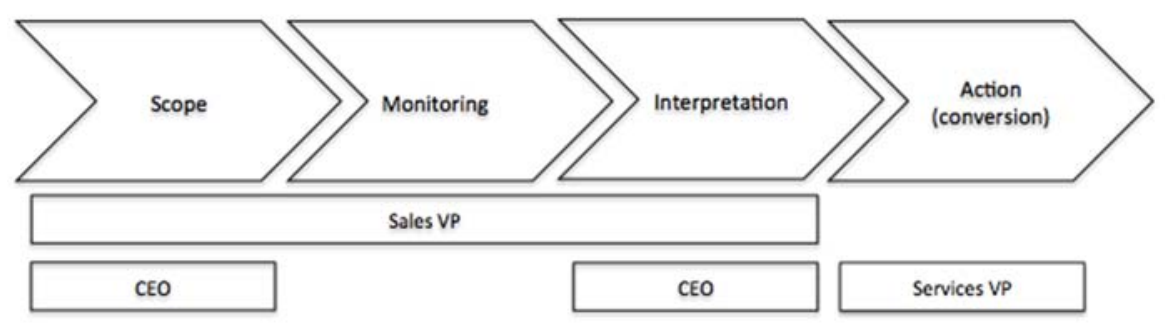

Source: Authors (2017).

The most important phases to the CEO are the Scope (Source) and the Interpretation. In his view, where to look is determinant for a company to innovate in an appropriate way. And how to interpret the signal is also very important,

The Operations VP sees the conversion phase as the most important. He says - it is easy to have ideas; the difficult is to implement them,

The sales VP thinks the three phases, scope, monitoring and interpretation as the most important phases;

It's interesting to perceive that the vision of each of the executive is somehow dependent of their function. The operations VP is in the delivery, trying to reach the goals, the SLAs (Service Level Agreements), therefore he is involved in execution. The sales VP has a close vision to the CEO, they understand the beginning of the process is very important; once you have it started wrong, it is too costly to correct the goal. Also, they have in common the interpretation; they say it is very difficult to interpret it in a "right way".

\subsection{The leadership vision about the innovation concept}

An interesting point is about the innovation concept definition in the leadership perspective. Even for the top management, in the highest level of the regional hierarchy, and very close to the strategic global level, what is innovation is not clear or at least not aligned with the innovation types as described in the OECD (2005, p. 14; p. 45- 48), Chang, Linton and Chen (2012) as: innovation in product, innovation in process, innovation in marketing, organizational innovation (divided in structural innovation and procedural innovation), and innovation in business models. Their views about innovation concept are associated mainly to new product creation, and obtained essentially by resource and development (R\&D) function or department. They didn't know about, for instance, process innovation, or organizational innovation, even they practiced these kinds of innovations.

\section{CONCLUSION}

As a contribution of this work, from a theoretical perspective, it was confirmed that the Peripheral Vision and Absorptive Capacity are valid mechanisms for innovation generation, and an instrument for examining the firm's innovative performance in acquiring signals in the market. Additionally, it was possible to evaluate a t-KIBS service company strategy and practice acting in the innovation process. From a managerial point of view, this study contributes to identify factors that affect the acquisition, monitoring and interpretation of market signals, enabling an increase in the number of opportunities for innovation generation. Also it was possible to observe an ambidextrous operation working with both innovation and execution. 


\subsection{Limitations and future studies}

One company case study can bias the study and possible conclusions, and so can the informant number of three. A suggestion would be to study another companies in the same industry segment (t-KIBS) with the same leadership level. In the same company talk to global people to have a global perspective instead of a regional subsidiary perspective.

\section{REFERENCES}

ARMBRUSTER, $\mathrm{H}$. et al. Organizational innovation: The challenge of measuring non-technical innovation in large-scale surveys. Technovation, n. 28, p. 644-657, 2008.

BEKHET A.; ZAUSZNIEWSKI, J. Methodological triangulation: an approach to understanding data. Nurse Researcher, $\mathrm{v}$. 20, n. 2, p. 40-43. 2011.

CHANG, C.; LINTON, D. J.; CHEN, M. Service regime: An empirical analysis of innovation patterns in service firms.

Technological Forecasting \& Social Change, n. 79, p. 1569-1582, 2012.

CHRISTENSEN, C. M. The Innovator's Dilemma - When New Technologies Cause Great Firms to Fail. Boston: Harvard Business School Press, 1997.

COHEN, W.M.; LEVINTHAL, D.A. Absorptive Capacity: A New Perspective on Learning and Innovation. Administrative Science Quarterly, v. 35, p. 128-152, 1990.

CROSSAN, M. M.; APAYDIN, M. A Multi-Dimensional Framework of Organizational Innovation: A Systematic Review of the Literature. Journal of Management Studies, v. 47, n. 6, p. 1154-1191, 2010.

DAY, G.S.; SCHOEMAKER, P.J.H. Peripheral Vision: seven steps to seeing business opportunities sooner. Boston: Harvard Business School Press, 2005.

EISENHARDT, K.M. Building Theories from Case Study Research, Academy of Management Review, v. 14, n. 4, p. 532$550,1989$.

GARTNER. Gartner Worldwide IT Spending Forecast. Available in:

<http://www.gartner.com/technology/research/it-spending-forecast/>. Accessed in 30 Sept. 2016.

GREMLER, D.D. The critical incident technique in service research. Journal of Service Research, v. 7, n. 2, p. 65-89, 2004.

HOWELLS, J. Innovation and Services: new conceptual frameworks. CRIC. Discussion Paper, n. 38, Aug. 2000.

HOWELLS, J. et al. Innovation in Services: Issues at Stake and Trends. [Research Report]. European Commission. 2004. Available in: < https://hal.archives-ouvertes.fr/halshs-01113600/document>. Accessed in 30 Sept. 2016.

KON, A. Economia de Serviços: Teoria e Evolução no Brasil. Rio de Janeiro: Campus/Elsevier, 2004.

LAURSEN, K.; SALTER, A. Open For Innovation: The Role of Openness. Strategic Management Journal, n. 27, p. 131150, 2006.

LEWIS, M.W. Iterative triangulation: a theory development process using existing case studies, Journal of Operations Management, n. 16, p. 455-469, 1998.

MARCH, J. G. Exploration and Exploitation in Organizational Learning. Organization Science, v. 2, Issue 1, p. 71-87, 1991.

MILES, I. et al. W. Knowledge-Intensive Business Services: Users, Carriers and Sources of Innovation. Prest Rapport pour 
DG 13. 1995.

OCDE. Oslo Manual: Proposed Guidelines for Collecting and Interpreting Technological Innovation Data. Paris: OCDE, 2005.

O'REILLY, C.A.; TUSHMAN, M.L. Ambidexterity as a dynamic capability: Resolving the innovator's dilemma. Research in Organizational Behaviour, v. 28, p. 185-206, 2008.

RAPPAPORT, D. The Science of Peripheral Vision. Available in: <http://www.sportsvisionmagazine.com/training/vision/pv001.html>. Accessed in 2 nov. 2014.

REGNÉR, PATRICK, Strategy Creation in the Periphery: Inductive versus Deductive Strategy Making. Journal of Management Studies, v. 40, p. 57-82, 2003.

SCHOEMAKER, P.J.H.; DAY, G.S. How to make sense of weak signals. Sloan Management Review, v. 50, p. 80-89, 2009.

SENGE, P. M. The fifth discipline: The art and practice of the learning organization. New York: Doubleday/Currency, 1990.

TIDD, J.; BESSANT, J.; PAVITT, K. Managing innovation, integrating technological, market and organizational change. New Jersey: John Wiley and Sons, 2005.

UTTERBACK, J. M. The Process of Technological Innovation Within the Firm. Academy of Management Journal, v. 14, n. 1, p. 75-88, 1971.

WEICK, K. E. Sensemaking in organizations. California: Sage, 1984.

YIN, R. Estudo de caso: planejamento e métodos. 4. ed. Porto Alegre: Bookman, 2010.

ZAHRA, S.A.; GEORGE, G. Absorptive Capacity: A Review, Reconceptualization, and extension. Academy of Management Review, v. 27, n. 2, p. 185-203, 2002. 